\title{
Female labour force participation, fertility and public policy in Sweden
}

\author{
Marianne Sundström
}

Stockholm University, Stockholm, Sweden

Frank P. Stafford

University of Michigan, Ann Arbor, USA

Received 28 October 1991; final version received 21 April 1992

Sundström, M. and Stafford, F.P., 1992. Female labour force participation, fertility and public policy in Sweden. European Journal of Population Revue Européenne de Démographie, 8: 199-215.

Abstract. This paper analyzes the role of public policy for Sweden's combination of high female labour force participation and high levels of fertility in the late 1980s and early 1990s. We present the central elements in the tax and family policies and use a disaggregated approach to assess their impact on Swedish fertility and female labour force participation. We show that these policies stimulate both fertility and women's paid work by reducing the costs of having children while requiring parents to be employed to collect full benefits.

Sundström, M. et Stafford, F.P., 1992. Participation féminine au marché du travail, fécondité et politiques en Suède (en anglais). European Journal of Population/Revue Européenne de Démographie, 8: 199-215.

Résumé. Cet article analyse le rôle des politiques sur le lien entre une forte participation féminine au marché du travail et de hauts niveaux de fécondité en Suède, à la fin des années 1980 et au début des années 1990. Nous présentons d'abord les principaux éléments des politiques fiscales et parentales. Puis nous utilisons une approche désaggrégée pour mettre en évidence leur impact sur la fécondité suédoise et la participation féminine au marché du travail. Nous montrons que ces politiques stimulent à la fois la fécondité et le travail féminin rémunéré en

Correspondence to: M. Sundström, Demography Unit, Stockholm University, 10691 Stockholm, Sweden. 
réduisant les coûts en vue d'élever les enfants tout en demandant aux parents d'être actifs pour en recueillir les pleins bénéfices.

\section{Introduction}

Among European countries in the late 1980s and early 1990s Sweden has had both the highest female labour force participation rate and the highest total fertility rate, next to Ireland (2.13 in 1990). Sweden is also characterized by a relatively high average age of women at first birth and a high fertility rate for second and third births for educated women. Since fertility and female labor force participation often have been considered negatively related (see e.g. Bumpass, 1990), an analysis of the mechanisms behind the Swedish "world record" seems warranted. In this article we review the Swedish tax policies and family policies; policies which we believe have been crucial to Sweden's unique pattern. We compare Swedish fertility, female labour force participation and parental leave benefits to those of the EC countries. A disaggregated approach is used to assess the impact of the public policies, especially the parental leave programme, on female labor force participation and fertility in Sweden.

In 1974 Sweden became the first country to give both mothers and fathers the right to paid leave from work at childbirth. Parental leave initially covered six months, but was successively extended in the following years to cover 15 months as of 1990 . From a labour market perspective a key element of the programme is that benefits are related to work and income history: labour income is replaced at a rate of $90 \%$ of gross earnings, while those not in the labour market receive a minimal taxable flat payment. The system is financed out of general taxes so that employer payment is independent of system use by the firm's employees.

Besides parental leave, other important policy elements encouraging work and fertility are subsidized day care, flexible working hours, economic support to families with children and the tax structure. Subsidized childcare was expanded greatly during the 1970s, and, as with parental leave, programme benefits are dependent on market work. Further, during the last two decades part-time jobs with full social benefits have been easily available, and since 1979 all full-time 
employed parents of pre-school children have had the right to reduce their hours of work to 30 hours per week (Sundström, 1987, 1991a). In addition, the progressive structure of taxes in combination with separate taxation of spouses, introduced in 1971, creates incentives for more equal market work time of men and women (Gustafsson, 1992). A recent study by Flood (1990) estimated virtual equality of the marginal post-tax wage of adult men and women.

Since parental leave benefits are based on earnings and since earnings normally rise more rapidly during the early years of labor market experience, the Swedish leave policy is one of the factors contributing to the postponement of entry into motherhood until a woman has an established labour market position. The day care system makes it easier to continue a career after parental leave, the availability of part-time jobs facilitates combining family and work, and the tax system limits the effects of spouse's income. The joint influence of these labor market policies is to create a very different pattern from that observed, e.g. in the USA, where fertility is higher among younger women, and where childbearing is likely to result in lower lifetime career attainment.

In Section 2 we offer a review of Sweden's development of parental leave policy in conjunction with the related policies indicated above. In Section 3 we compare Swedish fertility, female labor force participation and parental leave benefits to those of the countries in the European Community. An assessment of the impact of the parental leave program on fertility and labour market behaviour of Swedish women is developed in Section 4.

\section{Swedish policies for combining family and work}

\subsection{The parental leave programme}

Employed Swedish women have had the right to maternal leave at childbirth with some pay since 1955, with length of leave increased in 1962. The current policy dates from 1974 when parental leave was extended to fathers and the pay level was raised to $90 \%$ of gross earnings up to a ceiling. ${ }^{1 *}$ Leave benefits can be shared by the parents. In 1974 parents were entitled to six months' leave. The

\footnotetext{
* Superscript numbers refer to notes in the Notes section before the References.
} 


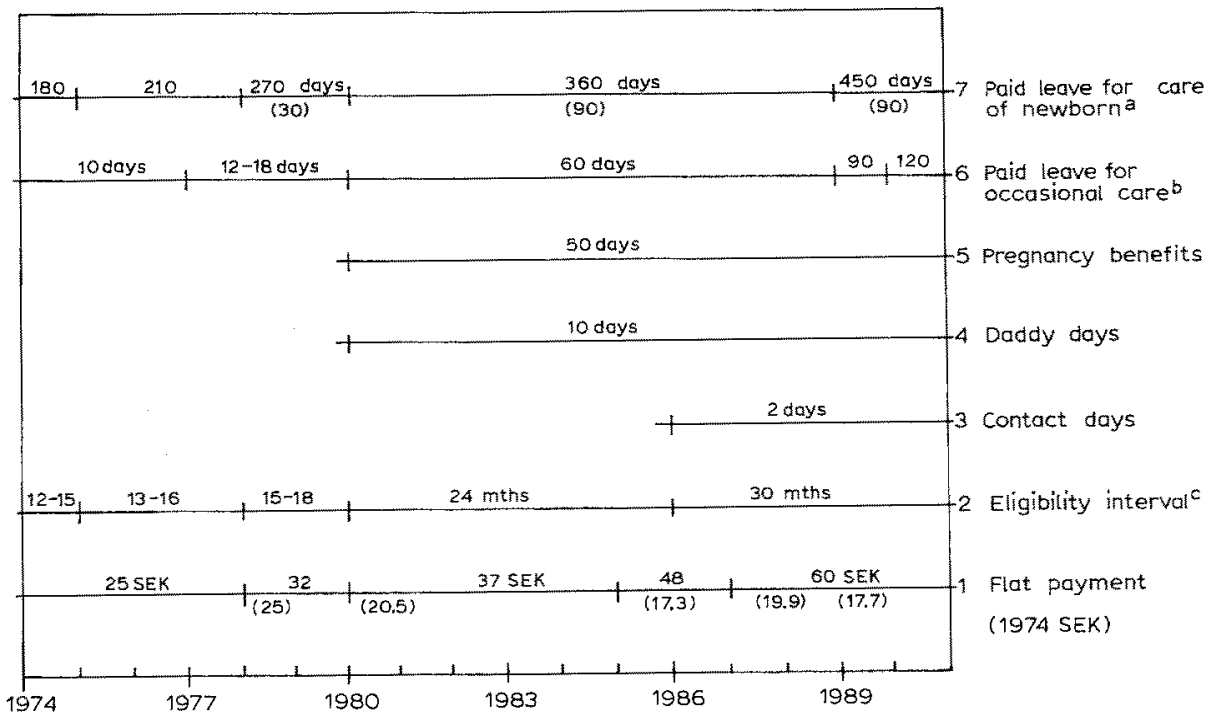

Fig. 1. Developments in parenting benefits in Sweden 1974-90. (Source: National Insurance Board. Various publications. ${ }^{a}$ Total number of paid leave days of which days at the flat rate in parentheses. In 1980, days with full pay were increased to 270 on 1 January and on 1 July 90 days at the flat rate were added. ${ }^{b}$ Before 1980 benefit days were counted per family with children under age 10; from 1980 benefit days are counted per child under 12 years of age. ${ }^{\circ}$ Maximum number of months between births for mother to remain at least at the benefit level of previous birth.)

benefit period was extended to seven months in 1975 and to nine months in 1978, the ninth of which was compensated at a flat rate equal for all recipients. In 1980 benefits were extended to 12 months and in 1989 to 15 months. Since 1980 the three last months of entitlement have been at the flat rate.

As of 1974 benefits could be used fill time or part time any time before the child is eight years old. Multiple births give a right to six months' extra benefits for each additional child. Also, benefits are taxable and pensionable. Fig. 1 summarizes the dates of introduction and revision of programme provision (see also Sundström [1991b]). Parents with no earnings prior to childbirth receive only the very low flat rate payment (of SEK 25 in 1974 and from 1987 SEK 60 per day $=19.91974 \mathrm{SEK}$ ) so the scheme provides women with a strong incentive to be employed prior to childbirth and even to postpone birth until earnings are sufficiently high. 
Before 1980 the benefits for leave with a subsequent child were usually based on the earnings record in the interval between births (with some local variation in the eligibility interval of about 12 months). This led to incentives to return to work and reestablish an earnings history between births, inducing a wider birth interval. Since 1980 , the system has encouraged a closer spacing of children. This is because, beginning in 1980 the level of monetary leave benefits would be at least as high as for the previous child if the next child was born within 24 months; in 1986 this limit was extended to 30 months. Also, this rule became statutory and more widely known. The extension of the period between births that generates eligibility for continued benefit level creates a more attainable target. It is now easier to include the period prior to the birth of the last child in the earnings history used to establish subsequent benefit levels; after 1980 a short interval of part-time earnings or unpaid leave between births became less likely to penalize the recipient. We refer to the policy established in 1986 as the " 30 -month rule".

In addition to the main benefits for the care of newborn children presented above, the parental insurance system currently includes three more benefits with the same income replacement: (1) pay for occasional care of children, i.e., benefits for care of children when they are sick or when their normal keeper is sick (from 1974); ${ }^{2}$ (2) a right for fathers only to 10 days of leave at childbirth (daddy days) (from 1980); and (3) the right to two days of benefit per year and per child aged 4-12 for parents' participation in day care and school activities (contact days) (from 1986). All four benefit provisions are financed through general taxes with no direct costs to the employer of the parent who uses benefits. Total government expenditure on parental benefits is estimated to reach SEK 17 billion in the fiscal year 1991/92 (Ministry of Finance, 1991), which is about 1\% of GNP. In addition, within the sickness insurance system there is a pregnancy benefit for pregnant women who cannot continue to work due to health limitations (from 1980).

In 1978 parents obtained the legal right to unpaid leave of absence from work with full job security after the standard parental leave had ended, and until the child was 18 months old. Furthermore, since 1979 all parents employed full-time have been granted the right to reduce their working hours to $75 \%$ of full-time (normally to 30 hours per week) until the child is eight years old, with a corresponding cut in 
pay. They also have the right to go back to full-time after three months' notice to the employer and they get full, but proportional, social benefits. ${ }^{3}$ A prerequisite for reducing hours is that one has been employed full time with the employer for at least six months.

\subsection{Swedish tax policies}

A second major influence on women's labour market activity are Sweden's tax policies. Married women's gainful employment was greatly encouraged through the introduction of separate taxation of married spouses from 1971. Without separate taxation the high rates and progressive structure of the Swedish tax system would have implied very low net earnings of married women whose husbands were significant earners, especially prior to recent tax reductions. For example, if both married partners earned an hourly wage equal to that of an average worker (male or female) in manufacturing industry, the marginal tax rate of a women working half-time with a spouse working full time fell from $55 \%$ in 1970 to $32.5 \%$ in 1971 (Tegle, 1985). ${ }^{4}$

The combination of individual taxation and highly progressive tax rates has favoured an equalization of participation and time spent in market work by husbands and wives (Burtless, 1987; Gustafsson, 1992) and a more equal division of time in housework (Juster and Stafford, 1991). Marginal tax rates for full-time workers rose steeply in the 1970 s to reach an all-time high of $64 \%$ for an average blue-collar worker in 1976, while those of half-time workers remained constant at about $32 \%$ throughout the decade (Tegle, 1985). ${ }^{5}$ As could be expected, these tax changes increased the attractiveness of part-time work over full-time work, especially for women, and so the proportion of employed women working part-time increased rapidly from $38 \%$ in 1970 to reach its peak at $47 \%$ in 1982 (Sundström, 1987, 1991a).

In 1982 Sweden had a tax reform cutting marginal national tax rates to a maximum of $50 \%$ for most income earners. Against the backdrop of rising part-time work of women and declining market hours of men throughout the $1970 \mathrm{~s}$, hours of work increased both among men and women, but more for the latter (Björklund et al., 1989). In particular, the proportion of employed women working part time declined back to $38 \%$ in 1990 , and hours worked among female part-time workers rose (Sundström, 1991c). In 1990 Sweden carried out another major tax reform which reduced marginal national tax rates to a maximum of 
$33 \%$ for most income earners from 1991. As female labor supply has proved to be more responsive to changes in the after tax wage than male labor supply (see e.g. Blomquist and Hansson-Brusewitz, 1990), this reform can be expected further of stimulate women's paid work.

\subsection{Day care and economic support}

A third factor affecting both women's labour market activity and fertility over the past two decades has been Sweden's development of a comprehensive system of public day-care facilities, including day care centres, family day care, part-time pre-school and after-school homes for pre-school children and young school children of working or studying parents. ${ }^{6}$ Day care services are provided by the 285 Swedish municipalities with extensive government subsidies; parents' fees are normally income related (lower for single parents) and cover an average of less than $10 \%$ of costs, which are currently about 60,000 SEK (about $\$ 10,000$ at the current exchange rate) per child per year.

To facilitate paid work for women the expansion of public day care was given high priority by the government in the 1970s. Government subsidies were raised significantly and the number of available spaces was quadrupled in that decade (Sundström, 1991b). In 1987 about $70 \%$ of children aged 1-6 years and $40 \%$ of the 7-9-year-olds had a place in public day care (Statistics Sweden, 1988). With extended parental leave benefits a small and declining proportion of children under one year of age use public day-care; only $2 \%$ in 1987 . In a study of local childcare markets, a strong effect of spaces per capita on the probability of substantial market work combined with public day care was found (Gustafsson and Stafford, 1992). In the absence of rationing, lower parents' fees significantly increased the probability of working in the market and using day care.

In addition, it should be noted that the system of family day care has the two-fold effect of, first, facilitating market work for those women whose children are cared for and, second, of enabling the child minder of having employment at the same time as she is at home caring for her own children (18\% of all children to six years old and $13 \%$ of the 7-10-year-olds were in family day care in 1988 [Statistics Sweden, 1989a]).

Fourth, since 1948 Sweden has given generous economic support to all families with children through the nontaxable child allowance of 
SEK 750 per child and month in 1991. In 1982 child allowances increments of $25 \%$ for the third child and $50 \%$ for the fourth and fifth children were introduced. These increments were raised in 1989 to $50 \%$ for the third child, $190 \%$ for the fourth, $240 \%$ for the fifth, and $160 \%$ for the sixth and additional children. As of 1991 the increment is $50 \%$ for the third child, $100 \%$ for fourth children and $150 \%$ for fifth and subsequent children. These allowances and increments are likely to have contributed to the increased propensity of Swedish women in the late 1980 s to bear a third and fourth child. In addition, Sweden's policies towards single single parents can be assumed to have had a positive impact on fertility. With the extensive support to single parents, mainly mothers (Gustafsson, 1990), women are less likely to refrain from childbearing due to fear of the consequences of divorce.

\section{Swedish fertility and female labor market activity in European comparison}

In European perspective Sweden is unique in combining the highest female labour force participation rate with the highest total fertility rate, next to Ireland's, in 1989 (Table 1). (In 1990 the Swedish total fertility rate was 2.13 while Ireland had 2.17.) In fact, levels of fertility in Sweden has never been as low as e.g. those of West Germany and Italy. The record-low total fertility rate was 1.6 in 1978 and 1983. This "world record" is likely to be the result of the comprehensive Swedish policies, described above, which facilitate combining family and market work.

All countries in the European Community have provided statutory rights to maternal leave at least since 1985. There are considerable cross-country differences in eligibility requirements, length leave and financial support. As to eligibility, Italy and Sweden stand at a one extreme; an Italian or Swedish woman needs only to be employed and insured at the beginning of her pregnancy in order to qualify. At the other extreme we have the uK where a woman must have national insurance coverage and two years continuous employment (five years if working 8-15 hours per week) to claim benefits. The level of benefits is as high as in Sweden or higher in some countries (Germany, Greece, Portugal and the Netherlands) but in these cases the potential duration of benefits is far less. 
Table 1

Total fertility rate, female labour force participation rate and statutory parental leave benefits in the Nordic and EC countries

\begin{tabular}{|c|c|c|c|c|}
\hline & $\begin{array}{l}\text { TFR } \\
1988\end{array}$ & $\begin{array}{l}\text { FLFPR } \\
1988 \\
\%\end{array}$ & $\begin{array}{l}\text { Maternity } \\
\text { leave } \\
1989 / 90 \\
\text { max. weeks }\end{array}$ & $\begin{array}{l}\text { Benefit } \\
\text { rate } \\
1989 / 90 \\
\%\end{array}$ \\
\hline Belgium & 1.57 & 51.4 & 14 & $4.5 w 100 \%+8.5 w 80 \%$ \\
\hline Denmark & 1.56 & 78.3 & 28 & $90 \%^{\mathrm{b}}$ \\
\hline Finland & 1.7 & 73.0 & 52 & $80 \%$ \\
\hline France & 1.82 & 55.7 & $16-28^{c}$ & $84 \%$ \\
\hline Germany & 1.42 & 54.4 & 14 & $100 \%$ \\
\hline Greece & 1.52 & 43.4 & 14 & $100 \%$ \\
\hline Ireland & 2.17 & 37.6 & 14 & $75 \%$ \\
\hline Italy & 1.34 & 43.9 & 47 & $22 \mathrm{w} 80 \%+25 \mathrm{w} 30 \%$ \\
\hline Luxemburg & 1.51 & 47.6 & 16 & $100 \%$ \\
\hline Netherlands & 1.55 & 51.6 & 16 & $100 \%$ \\
\hline Norway & 1.84 & 72.8 & 22 & $100 \%$ \\
\hline Portugal & 1.53 & 59.1 & 13 & $100 \%$ \\
\hline Spain & 1.38 & 39.4 & 14 & $75 \%$ \\
\hline Sweden & 1.96 & 80.1 & 65 & $52 \mathrm{w} 90 \%+13 \mathrm{w}$ SEK $60 /$ day \\
\hline UK & 1.84 & 63.5 & 18 & $6 w 90 \%+12 w £ 36.25$ \\
\hline
\end{tabular}

Sources: TFR: Eurostat (1991), Official Statistics of Finland, Norway and Sweden. FLFPR: OECD (1990) p. 200. Leave benefits: OECD (1990) p. 144, Stein (1989), David and Starzec (1991), Knudsen (1990).

a In Denmark and Ireland 4 weeks must be used prior to birth, in France 6-10 weeks, in Germany, Greece and the Netherlands 6 weeks and in Italy 8 weeks. In the Nordic countries, a part of the leave period can be used by the father.

b Benefits are $90 \%$ of earnings up to a ceiling of DKK 2.397 per week but some white collar workers, e.g. civil servants, get negotiated benefits equal to their full wage from their employer.

c 16 weeks for the first and second child, 28 weeks for third or higher.

Sweden is also the only country where the parents can share the whole leave period as they see fit. In Denmark the father can use at most 10 of the 28 weeks, in Finland 23 of the 52 weeks and in Norway at most 18 of the 24 weeks. For the other countries in Table 1 the leave period is limited to the mother. However, since 1990 some EC countries have introduced a period of paternity leave (paid or unpaid) to be used after the maternity leave.

It is interesting to compare Sweden to Denmark and Norway, the countries most similar to Sweden. They have almost as high female labour force participation rates as Sweden and fairly extensive daycare, but lower total fertility rates. This difference must surely be 
connected with differences in the family policies of the countries, since these have long been much less generous than Sweden's (Hoem and Hoem, 1988).

To assess the impact of parental leave policy on female employment and fertility in Sweden, in the next section we will utilize a disaggregated approach with an emphasis on studies of individual and household behaviour in Sweden.

\section{Impact assessment}

\subsection{Use of parental leave benefits in Sweden}

As in other countries with parental leave policies, by far the major share of benefits for care of newborn children in Sweden is used by mothers. Campaigns have been conducted to encourage fathers to make greater use of parental benefits, however, and there has been some response. Thus, of total days replaced, fathers used $7.5 \%$ in 1987 , a slight increase from $4.3 \%$ in 1978 , and $24.5 \%$ of all fathers used some benefits in 1987, a rise from $20.4 \%$ in 1978 . Fathers who received benefits were on leave for 29.3 days on average in 1987 compared to only 10.9 days in 1978 (National Insurance Board, 1989). However, among married and employed parents, fathers who used any benefits were on leave for more days; 43 days on average for children born in January and February 1989 (National Insurance Board, 1990). Also, the proportion who had shared the leave was much higher among these parents, namely $44 \%$ for children born in January and February 1989, and the fraction had risen steeply from $27 \%$ for children born in 1981 by the same type of families (National Insurance Board, 1985). The extension of the paid leave period in 1989 may have contributed to the rise in the fraction of fathers who take any leave.

The willingness of married and employed fathers to take out any parental leave has been found to depend more on the size of their wives' earnings than on their own; the higher the pay of the mother, the larger was the proportion of fathers that had received benefits. This holds regardless of the fathers' earnings (National Insurance Board, 1985). Also, based on a sample of parents of 1,000 children born in 1986, fathers employed in the public sector were found more likely to have used at least one month of full-time benefits than were 
those employed in the private sector. Fathers who held management or supervising positions had used the full-time leave option to a lesser extent than others. By contrast, fathers who had been on parental leave for at least one month more often worked at female-dominated work places (Näsman, 1992; see also Haas, 1990).

\subsection{Work-history changes}

Impacts of the joint policy influences can be seen in disaggregated time series. 15 panels of female respondents were specially compiled from the Swedish Labour Force Surveys (LFS) from the period $1970 / 72-1988 / 90{ }^{7}$ Each panel contained observations for a survey week in each of eight months three months apart. Information in each survey round included respondent's employment status as well as presence and age of children. From these data one can observe changes in employment status including changes for women who gave birth during the time they were in the survey (Sundström, 1987, 1991c).

The results show that to an increasing extent Swedish women work full time up to the birth of their first child. They remain classified as employed full-time while on parental leave. ${ }^{8}$ With this convention the fraction of first-time mothers who were recorded in full-time work for eight quarters in a row up to, including and after childbirth rose from $25 \%$ in $1970 / 72$ to $48 \%$ in $1988 / 90$ (Table 2). Most likely, this steep rise is a manifestation of a combination of the leave policy and the

Table 2

Fractions continuously full-time employed, part-time employed and nonemployed among childbearing women in 1970-90 (in \%)

\begin{tabular}{lllcc}
\hline & & Full-time & Part-time & Nonemployed \\
\hline Women giving birth & $\mathbf{1 9 7 0 - 7 2}$ & 25.4 & 2.4 & 7.8 \\
to their first child & $1979-81$ & 31.1 & 9.9 & 6.1 \\
& $1980-82$ & 40.3 & 9.5 & 2.5 \\
& $1984-85$ & 39.2 & 11.8 & 6.1 \\
& $1988-90$ & 47.8 & 8.4 & 1.9 \\
Women having & $1970-72$ & 7.7 & 8.7 & 31.4 \\
higher-order births & $1979-81$ & 10.2 & 35.1 & 17.8 \\
& $1980-82$ & 11.9 & 36.1 & 12.4 \\
& $1984-85$ & 16.2 & 37.4 & 7.7 \\
& $1988-90$ & 19.9 & 25.6 & 5.9 \\
\hline
\end{tabular}

Source: The panel of the labor force surveys. See Sundström $(1987,1991 c)$. 
Table 3

Shifts between part-time and full-time work among childbearing women in 1970-90 (in \%)

\begin{tabular}{llll}
\hline & & $\begin{array}{l}\text { Percent changing } \\
\text { from full-time } \\
\text { to part-time }\end{array}$ & $\begin{array}{l}\text { Percent changing } \\
\text { from part-time } \\
\text { to full-time }\end{array}$ \\
\hline Women giving birth & $1970-72$ & 11.5 & 1.0 \\
to their first child & $1979-81$ & 24.4 & 3.9 \\
& $1980-82$ & 19.2 & 2.5 \\
& $1984-85$ & 12.7 & 0.8 \\
Women having & $1988-90$ & 6.9 & 2.9 \\
higher-order births & $1970-72$ & 3.3 & 0.7 \\
& $1979-81$ & 4.9 & 3.7 \\
& $1980-82$ & 8.3 & 6.6 \\
& $1984-85$ & 12.0 & 2.4 \\
\hline
\end{tabular}

Source: The panel of the labor force surveys. See Sundström $(1987,1991 \mathrm{c})$.

definitions used in the LFS. First, as pointed out above, the parental leave scheme gives women who plan to have children a strong incentive to work full-time prior to childbearing in order to increase subsequent benefits. Second, since women on parental leave from a full-time job are classified as employed full-time, extensions of the leave will increase the fraction recorded as full-time employed. We also see that virtually no first-time mothers are continuously nonemployed. Among women having higher-order births the proportion working continuously full time almost tripled over the 20 years studied. The rise was particularly steep in the late 1980s.

After parental leave, an increasing share of first-time mothers shifted from full-time mothers shifted from full-time to part-time work in the $1970 \mathrm{~s} ; 24 \%$ of all first-time mothers did so in $1979 / 81$ compared to $12 \%$ in $1970 / 72$ (Table 3 ). The fraction recorded as shifting to part time fell during the $1980 \mathrm{~s}$, particularly after 1988 . We believe that this was essentially due to the longer duration of leave benefits; the return to the labour market was progressively more likely to fall outside the eight-quarter period. Moreover, the extended leave period, the possibility of combining part-time benefits with part-time work and the statutory option to reduce weekly working hours option all must have contributed to reducing substantially the outflow of women from full-time to nonemployment at first birth from $18 \%$ in $1970 / 72$ to less than $5 \%$ in $1988 / 90$ (Sundström, 1991c, Table 6). 


\subsection{Child-spacing changes}

In Section 2 and Fig. 1 we pointed out that the interval between births that generates eligibility for leave benefits at least as high as for the previous child was made statutory and extended to 24 months in 1980 . In 1986 the eligibility interval was extended to 30 months. When the eligibility interval is as long as two years or more, many couples will find it quite manageable to have two children sufficiently closely spaced to maintain the initial level of benefit rights. If the next child comes after the end of the eligibility interval, the mother's income compensation will be eroded if she works part-time, as many mothers of pre-school children do in Sweden, or if she does not work in the labour market at all, which very few do. Thus, couples have an

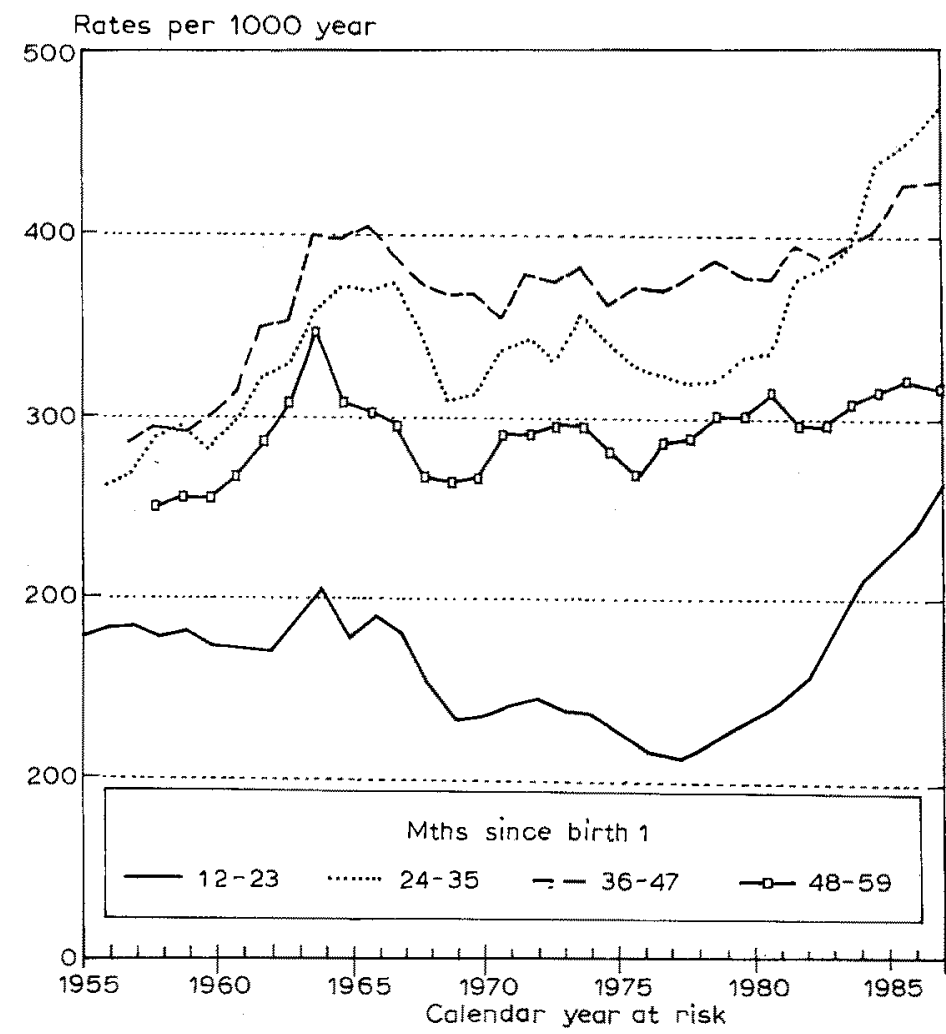

Fig. 2. Second-order birth rates of mothers with a first birth at ages $22-23$, by calendar year at risk, 1955-87 (Source: Statistics Sweden, unpublished data). 
incentive to stay within the eligibility interval. Given the uncertainties involved in conception and pregnancy, some will nevertheless overshoot the target and have the next child too late. In any case, we should expect the next-order birth rate to get a special boost when the previous child is one or two years old, and this is precisely what we can observe in Fig. 2. The curve for second births to mothers of one-year-olds is particularly step during the $1980 \mathrm{~s}$ and the curve for mothers of two-year-olds is almost as steep. Curves for mothers of older ages as well as for third births display the same pattern (Hoem, 1990). The shortening of birth intervals and the rise in the tempo of childbearing in the late $1980 \mathrm{~s}$, in turn, contributed to the rise in total fertility. Simply, it is likely that completed fertility will be greater when birth intervals are shorter than when they are longer. This is because with longer birth intervals childbirth can be offset by separation, sickness, etc.

\section{Conclusions}

Sweden in the late 1980 s and early 1990 s has combined the highest female labour force participation rate with the highest fertility rate, next to Ireland, among European countries. In this paper we have shown that this was not a mere coincidence: Sweden's comprehensive public policies fit together as a system which stimulates both fertility and women's gainful employment. In Sweden, the combination of high average and marginal tax rates with separate taxation of spouses has encouraged women's labour market activity. Also, the parental leave programme and the availability of subsidized childcare as well as flexible working hours have facilitated market work for women of childbearing ages. In combination, these policies reduce the cost of having children (as do the nontaxable child allowances) while at the same time requiring women to be employed in order to collect full benefits.

Of particular interest is the demonstrated impact on fertility of the extensions, in 1980 to 24 months and in 1986 to 30 months, of the interval between births that generates eligibility for parental leave benefits at least as high as those for the previous birth. In the second half of the 1980s the next-order birth rate got a special boost when the previous child was one or two years old. This is because couples has 
an incentive to stay within the eligibility interval which after the extensions constituted are more easily attainable target. Finally, it is likely that completed fertility will be higher when births are more closely spaced, since with longer birth intervals some births will not take place.

\section{Acknowledgements}

We would like to thank Jan Hoem for valuable comments and for his permission to use Fig. 2.

\section{Notes}

${ }^{1}$ The ceiling is set at 7.5 "base amounts". The "base amount" is a unit for calculation of pensions etc. in the Swedish social security system. In 1985 less than $1 \%$ of Swedish women and less than $10 \%$ of Swedish males had earnings that exceeded 7.5 base amounts (National Insurance Board).

${ }^{2}$ In March 1991 the income compensation for occasional care of children was reduced to $80 \%$ for the first two weeks. After that $90 \%$ is replaced, which still applies to the other parental benefits from the first day.

${ }^{3}$ Government employees have had this right for children up to age 12 since 1970.

${ }^{4}$ By this measure female earnings and tax rates are slightly overestimated since adult female workers in manufacturing industry received $85 \%$ of the average hourly wage in 1970. Also, while average yearly earnings of all Swedish women employed full-time and full-year was SEK 39,200 in 1975, the yearly wage of a worker in manufacturing industry was SEK 45,800 , on average (Sweden's Official Statistics).

${ }^{5}$ See note 4 .

${ }^{6}$ Children with special needs get priority to a place at a day care centre, however.

7 The Labour Force Surveys include many variables and are carried out monthly to a sample of (from 1988) 18,000 individuals representative of the Swedish population of ages 16-64 years. The panels refered to here are based on interviews with 8,000-10,000 women (see Statistics Sweden 1989b, 1990).

${ }^{8}$ By international standards all persons who have a job and are absent from work during a survey week, whether it is because they are sick, on vacation or on leave, are classified as employed in the Labour Force Surveys.

\section{References}

Björklund, A., Hamilton, C.B., Jacobsson, U., Jönsson, B. and Söderström, H.T., 1989. Den svenska modellen inför 90-talet. SNS Förlag, Stockholm. 
Blomquist, N.S. and Hansson-Brusewitz, U., 1990. The effect of taxes on male and female labor supply in Sweden. Journal of Human Resources, 25: 317-357.

Bumpass, L.L., 1990. What's happening to the family? Interactions between demographic and institutional change. Demography, 27 (4): 483-498.

Burtless, G. 1987. Taxes, transfers, and Swedish labor supply. In: B.P. Bosworth and A.M. Rivlin, eds. The Swedish Economy. Brookings Institution. Washington, DC: 185-242.

David, M.-G. and Starzec, C., 1991. France: a diversity of policy options. In: S.B. Kamerman and A.J. Kahn, eds. Child Care, Parental Leave, and the Under 3s Policy Innovation in Europe. Auburn House, Westport, CT: 81-113.

Eurostat, 1991. Demographic Statistics 1991. Eurostat, Luxembourg.

Flood, L., 1990. Aft mäta och estimera utbudet av arbetskraft, 1990. In: A. Klevmarken, ed. Tid och råd. Industrial Institute for Economic and Social Research, Almqvist \& Wiksell, Stockholm: 75-97.

Gustafsson, S., 1990. The labor force participation and earnings of lone parents. In: Lone Parent Families: the Economic Challenge. OECD, Paris: 151-172.

gustafsson, S., 1992. Separate taxation and married women's labor supply: a comparison of West Germany and Sweden. Journal of Population Economics, 5: 61-85.

Gustafsson, S. and Stafford, F.P., 1992. Childcare subsidies and labor supply in Sweden. Journal of Human Resources, 27 (1): 204-230.

Haas, L., 1990. Equal parenthood and social policy: a study of parental leave in Sweden. Unpublished manuscript, Department of Sociology, Indiana University, IN.

Hoem, B. and Hoem, J.M., 1988. The Swedish family: aspects of contemporary developments. Journal of Family Issues, 9: 397-424.

Hoem, J.M., 1990. Social policy and recent fertility change in Sweden. Population and Development Review, 16: 735-748.

Hoem, B. and Hoem, J.M., 1988. The Swedish family: aspects of contemporary developments. Journal of Family Issues, 9: 397-424.

Juster, F.T. and Stafford, F.P., 1991. The allocation of time: empirical findings, behavioral models, and problems of measurement. Journal of Economic Literature, 29: 471-522.

Knudsen, R., 1990. Familieydelser i Norden 1989. Teknikse rapporter No. 52, Nordisk Statistisk Sekretariat, Copenhagen.

Ministry of Finance, 1991. Regeringens budgetförslag 1991/92. Allmänna Förlaget, Stockholm.

Näsman, E., 1992. Föräldraledighetslagen i tillämpning. Work in progress, Demographic Unit, Stockholm University, Stockholm.

National Insurance Board, 1985. Föräldraledighet i samband med barns födelse. Barn födda 1978-1982. Statistisk rapport 1985: 4, National Insurance Board, Stockholm.

National Insurance Board, 1989. Föräldrapenning med anledning av barns födelse avseende 1988. Statistik information Is-I 1989: 24, National Insurance Board, Stockholm.

National Insurance Board, 1990. Uttag av föräldrapenning med anledning av barns födelse under barnets första levnadsắr. Statistik information Is-I 1990: 16, National Insurance Board, Stockholm.

OECD, 1990. Employment Outlook. OECD, Paris.

Statistics Sweden, 1988. Barnomsorgsundersökningen 1987. Statistics Sweden, Stockholm, 1988.

Statistics Sweden, 1989a. Barnomsorgsundersökningen 1988. Statistics Sweden, Stockholm.

Statistics Sweden, 1989b. Revision of Contents and Definitions in the Swedish Labour Force Surveys 1989: 3. Statistics Sweden, Stockholm.

Statistics Sweden, 1990. The Swedish Labour Force Surveys 1990: 3. Statistics Sweden, Stockholm.

Stein, G., 1989. Det sociala skyddsnätet i Sverige och EG, Aktuell information. Näringslivets Ekonomifakta, Stockholm. 
Sundström, M., 1987. A Study in the Growth of Part-time Work in Sweden. Swedish Center for Working Life, Almqvist \& Wiksell, Stockholm.

Sundström, M., 1991a. Part-time work in Sweden: trends and equality effects. Journal of Economic Issues, 25: 167-178.

Sundström, M., 1991b. Sweden: supporting work, family, and gender equality. In: S.B. Kamerman and A.J. Kahn, eds. Child Care, Parental Leave, and the Under 3s Policy Innovation in Europe. Auburn House, Westport, CT: 171-199.

Sundström, M., 1991c. The growth in full-time work among Swedish women in the 1980s. Paper presented at the 3rd EALE-Conference, El Escorial, Madrid.

Tegle, S., 1985. Part-time employment. Lund Economic Studies No. 35, Department of Economics, University of Lund. 